\title{
Induced pluripotent stem cell potential in medicine, specifically focused on reproductive medicine
}

\author{
Olivier Botman ${ }^{1}$ and Christine Wyns ${ }^{1,2}$ * \\ 'Gynecology Unit, Medical School, Institut de Recherche Expérimentale et Clinique, Université Catholique de Louvain, Brussels, Belgium \\ ${ }^{2}$ Cliniques Universitaires Saint-Luc, Université Catholique de Louvain, Brussels, Belgium
}

\section{Edited by:}

Issam Lebbi, Alyssa Polyclinics for Woman, Mother and Child, Tunisia

Reviewed by:

Anis Feki, Hôpitaux Fribourgeois, Switzerland

Diane De Neubourg, University

Hospitals Leuven, Belgium

${ }^{*}$ Correspondence:

Christine Wyns, Cliniques

Universitaires Saint-Luc, Université

Catholique de Louvain, Avenue

Hippocrates 10, Brussels 1200,

Belgium

e-mail: christine.wyns@uclouvain.be
Since 2006, several laboratories have proved that somatic cells can be reprogramed into induced pluripotent stem cells (iPSCs). iPSCs have enormous potential in stem cell biology as they can give rise to numerous cell lineages, including the three germ layers. In this review, we discuss past and recent advances in human iPSCs used for modeling diseases in vitro, screening drugs to test new treatments, and autologous cell and tissue regenerative therapies, with a special focus on reproductive medicine applications. While this latter field of research is still in its infancy, it holds great promise for investigating germ cell development and studying the genetic and physiopathological mechanisms of infertility. A major cause of infertility is the absence of germ cells in the testes, mainly due to genetic background or as a consequence of gonadotoxic treatments. For these patients, no effective fertility restoration strategy has so far been identified. The derivation of germ cells from iPSCs represents an alternative source of stem cells able to differentiate into spermatozoa. Lessons learned from animal models as well as studies on human iPSCs for reproductive purposes are reviewed.

Keywords: human induced pluripotent stem cells, primordial germ cells, human germ cell differentiation, embryonic cells, infertility

\section{INTRODUCTION}

By definition, stem cells can differentiate spontaneously into all cell types that form the human body. They have the ability to both differentiate into other mature cell types and maintain an undifferentiated state by self-renewal. These unique properties form the basis for stem cell use in cell and tissue regeneration. Currently, embryonic stem cells (ESCs) are the most widely studied stem cell type. ESCs arise from culture of primitive ectoderm cells of the inner cell mass of blastocysts and show pluripotency properties. Under strict culture conditions, they can perpetuate their undifferentiated pluripotent state indefinitely and are therefore an in vitro derivative without a specific in vivo counterpart. Since the first human ESC (hESC) line was obtained in 1998 by Thomson (1), numerous hESC lines have been recorded in the hESC registry [www.hESCreg.eu (2)]. However, some ethical issues regarding the use and destruction of human embryos, as well as concerns about genetic identity or immunological rejection by the recipient $(3,4)$, represent serious limitations for hESC application in humans. Obtaining pluripotent stem cells from alternative sources such as adult somatic cells, known as induced pluripotent stem cells (iPSCs), has therefore been contemplated. The aim of this review is to present their current applications and investigate their potential use in clinical practice in the light of animal studies.

The first iPSC lines were generated from adult fibroblasts by retrovirus-mediated introduction of four transcription factors into the genome of somatic cells (OCT4, SOX2, C-MYC, and KLF4) (5). OCT4 (6) and SOX2 (7) are core transcription factors of pluripotency, while C-MYC (8) and KLF4 (9) are involved in selfrenewal. Retroviruses appear to be required only for induction of pluripotency and not for its maintenance, as demonstrated after strong silencing of the four retroviruses (10). Epigenetic reprograming of autologous somatic cells into PSCs has attracted much attention because of the potential for autotransplantation therapy, as cellular derivatives of reprogramed cells will not be rejected by the recipient and there are no ethical concerns as for embryonic cells. iPSCs have been shown to be equivalent to ESCs in terms of morphology, surface markers, gene expression, proliferation capacity, and differentiation (11). Indeed, karyotype analysis revealed no notable difference in the incidence of chromosomal aberrations in iPSCs compared to hESCs (12). Although reprograming occurs at a very low frequency and with only partial epigenetic reprograming, as determined by the methylated status of OCT4 in iPSCs cells (13), it appears to be sufficient to generate reprogramed cell lines that can be used in vitro indefinitely.

\section{MATERIALS AND METHODS}

We conducted an extensive Medline search using the following search terms: iPSCs and germ cell differentiation. A total of 5897 articles dating from 1967 to 2013 were initially retrieved. Since the topic is innovative, original articles of any design and review articles published in English and French were suitable for inclusion. Selection criteria were based on the main outcome of interest referenced in this baseline of articles, namely the potential in reproductive medicine of iPSCs reprogramed from animal and human somatic cells, including differentiation into germ lines and infertility modeling, with a view to synthesizing the state of current knowledge for clinical applicability in humans. Regarding issues connected to the main subject, namely use of iPSC line 
differentiation to (a) understand the physiopathology of diseases, (b) study the efficacy and toxicology of new medical therapy, and (c) regenerate cells and tissues, the goal was to introduce the reader to the literature, rather than provide an exhaustive review. The final number of studies referenced in this review is 135 .

\section{iPSCs USED TO STUDY/UNDERSTAND DISEASES}

Since the creation of the first-line of iPSCs from mature adult cells by Takahashi and Yamanaka (5), generating patient-specific stem cells through reprograming has become almost routine. iPSC technology provides a uniquely useful disease-specific tool to analyze normal development, outline disease features, and study the physiopathological and genetic mechanisms of the disease in vitro. With the increase in stem cell line collection during the past few years, disease models have been created from human adult somatic cells by reprograming. Although iPSCs can be patently derived from any type of somatic cells, they are mostly reprogramed from skin fibroblasts, due to ease of accessibility. Table 1 summarizes fully differentiated disease-specific iPSC lines obtained from somatic cells so far, as well as iPSCs used for physiopathological screening and drug testing (Table A1 in Appendix).

\section{iPSCs: TOXICOLOGY STUDIES AND NEW MEDICAL TREATMENTS}

Induced pluripotent stem cells technology provides a unique platform to identify possible therapeutic agents, evaluate their efficacy and toxicity, and study gene repair associated with cell replacement therapy. Indeed, derivation of patient-specific familial dysautonomia (FD) iPSCs (14) illustrates the potential of iPSC technologies for modeling therapeutic action in human disease in vitro. FD is a peripheral neuropathy caused by a point mutation in the IKBKAP8 gene, characterized by depletion of autonomic and sensory neurons. After differentiation of FD iPSCs into peripheral neurons, the effect of candidate drugs in reversing aberrant splicing and improving neuronal differentiation and migration may be studied. In addition, while kinetin was reported to affect splicing and absolute levels of IKBKAP8 (15), exposure of FD-iPSC-derived neural crest precursors to kinetin was shown to result in a dramatic reduction in the mutant IKBKAP8 splice form and a significant increase in the percentage of differentiating neurons under continuous kinetin treatment, demonstrating the potential usefulness of disease-specific iPSCs in developing new drug therapies.

Use of cardiomyocytes differentiated from human catecholaminergic polymorphic ventricular tachycardia (CPVT) iPSCs has provided insights into arrhythmia mechanisms in CPVT, a calcium-dependent familial arrhythmogenic disorder associated with dominant mutations in the cardiac ryanodine receptor gene, allowing screening of the effects of disease aggravators (adrenergic stimulation) and drug treatments (beta blockers and flecainide) (16). Analysis of the iPSC line showed mutation into the ryanodine receptor gene to be linked with altered calcium release, and found tested treatments to be effective in vitro.

These latter developments demonstrate the feasibility of using in vitro iPSC differentiation assays for drug testing, providing a unique tool in the presence of in vivo study limitations in humans. Thus, human iPSCs may be used for personalized medicine, with pharmacological and toxicological tests designed and performed on an individual's genome.

\section{iPSCs FOR CELL/TISSUE REGENERATIVE THERAPY: FROM ANIMAL TO HUMAN APPLICATION}

Beyond in vitro use of human iPSC lines, clinical application of iPSC therapies seems rather unrealistic (see iPSCs Differentiation into Male Gamete Lineage). However, a number of studies in animals have opened new perspectives for human therapeutic

Table 1 | Differentiation of human iPSCs into male germ cell lineage.

\begin{tabular}{lllll}
\hline Reference & Cell source & Additional factors & In vitro-derived cells & Main evaluation \\
\hline (42) & Fibroblast $X Y$ & Fetal gonadal cells & PGCs & $\begin{array}{l}\text { Expression (STELLA, VASA, ACROSIN) } \\
\text { Genomic imprint (H19, PEG1) }\end{array}$ \\
(31) & Fibroblast XY, XX & RA, forskolin, and CYP26 & PGCs spermatids & Expression (VASA, SYCP3) \\
& & & Genomic imprint (H19) \\
& & & Genome ploidy \\
(40) & Fibroblast XY, XX & BMP 4, 7, and 8 & Spermatids & Expression (VASA, ACROSIN) \\
& FAZ family overexpression & & Genome ploidy \\
(39) & VASA/DAZL overexpression & Spermatids & Expression (VASA, ACROSIN) \\
& & & Genomic imprint (H19) \\
& & & Genome ploidy \\
(43) & Fibroblast $X X, X Y, X X Y$ & BMP 4, 7, and 8 & PGCs & XCl (H3K27me3, macroH2A1) \\
& & & Transcriptome of differentially expressed X-linked genes \\
(38) & Fibroblast $X Y$ & SSCs spermatocytes & Expression (VASA, ACROSIN) \\
& & Spermatids & Genomic imprint (H19, IGF2)
\end{tabular}

$R A$, retinoic acid; CYP26, cytochrome P26; BMP, bone morphogenic protein; XCl, X chromosome inactivation; DEG, differentially expressed gene; SSC, spermatogonial stem cell. 
applications. In 2007, Hanna and colleagues treated a humanized mouse model of sickle-cell anemia by transplantation of iPSCs derived from mouse skin cells repaired with a homologous recombination. Transplanting these repaired iPSCs differentiated into hematopoietic progenitors led to correction of the disease phenotype in the sick mice (17). In 2008, Wernig derived dopaminergic neurons from iPSCs and found, after engrafting into the brain, that they survived, were functional and able to partially rescue a rat model of Parkinson's disease $(18,19)$. These two studies, showing stable and functional engraftment of repaired specific iPSCs, demonstrate the huge potential of iPSC-based treatment. Moreover, human iPSCs have already shown beneficial effects after their differentiation and transplantation into mouse-specific disease models. Transplantation of human iPSCs into the subretinal space of a mouse model of retinitis pigmentosa after differentiation into functional retinal pigmented epithelial tissue showed stable long-term engraftment, assimilation into the host retina without disruption, and improved visual function over the lifetime (20). These results, and the absence of tumor development in transplanted mice, suggest that such therapies would be transposable to human clinical practice and would improve classical treatment.

In humans, a number of clinical studies have already revealed the benefits of autologous non-iPSC transplantation, particularly for functional recovery (21-23). While use of iPSCs as a source for autologous stem cell transplantation is still in its infancy, some iPSC applications in humans are well on the way to being introduced into a clinical setting. Indeed, insulin-producing cells derived from human iPSCs have already been obtained in vitro for potential therapeutic use in diabetes (24).

\section{iPSCs AND REPRODUCTION}

There is no doubt that parenthood plays an important role in quality of life, so fertility preservation or restoration strategies need to be developed for infertile patients. Storage of spermatozoa, oocytes, or ovarian tissue should be the first-line treatment approach, as their reproductive potential after freezing has already been proven in humans. However, storage of mature or immature germ cells is not always possible, either because of lack of time in an emergency context like cancer therapy, or inaccessibility to the technique at the time of disease management. For these patients, generation of gametes from iPSCs would be an innovative strategy that could give them hope of becoming parents. Use of non-gametogenic pluripotent stem cells as a source of germ cells could also benefit patients suffering from congenital diseases affecting reproduction, such as Klinefelter syndrome, Y chromosome microdeletions, and Turner syndrome, who may have already lost their germ cells at the time of diagnosis. It could also be effective for patients whose germ cells are not functioning, for instance boys with cryptorchid testes.

During embryonic development, primordial germ cells (PGCs), differentiated from epiblast cells, are identifiable at 4 weeks of gestation and migrate through the epiblastic crest to colonize the gonadal ridges by 7 weeks of gestation $(25,26)$. While migrating, PGCs proliferate intensively and begin extensive nuclear reprograming to regain self-renewal capacities and reset their genomic imprinting. Germ cells are highly specialized cells established by a specific transcriptional program, including repression of somatic fate and regulation of the extensive epigenetic reprograming of the genome (27). Cells that undergo differentiation into PGCs show expression of some key pluripotency-specific genes that appear to play a role in germ cell specification in mammals, such as Blimp 1 (or Prdm1) (28) and Prdm 14 (29). These processes are completed after reaching the gonadal ridge. After some rounds of proliferation, PGCs finally differentiate into oogonia or gonocytes within the sex cords for female and male individuals respectively.

Due to the complexity of gametogenesis in vivo, mimicking germ cell differentiation in vitro will help us better understand the regulation of developmental programs, such as specification, migration, and sex determination, which allow transmission of genetic information and creation of new human beings. The capacity of iPSCs to differentiate into germ cells of both genders has been tested in several species, and recent studies have demonstrated that PGCs can be obtained by in vitro differentiation of iPSCs, producing functional gametes and offspring in mice (10). In an attempt to shed new light on the benefits of using iPSCs in reproductive medicine, this review focuses on results obtained from differentiation of mouse and human iPSCs into germ cell lineage.

\section{iPSCs DIFFERENTIATION INTO MALE GAMETE LINEAGE Lessons learned from animal models}

Spontaneous differentiation of iPSCs occurs after 4-7 days of culture and is highly variable and inconstant, resulting in different cell types from the three germ layers (endoderm, mesoderm, and ectoderm) in varying amounts. Several studies have reported derivation of germ cell precursors and gametes from mouse iPSCs. Injection of iPSCs into blastocysts generated chimeric pups, and analysis of host organs demonstrated the extensive contribution of injected iPSCs to various organs, including the eyes, ears, tail, claws, kidneys, liver, lungs, stomach, guts, and testes (30), confirming the potential of iPSCs to form gametes in vivo. Differentiation of iPSCs to PGCs occurs in vitro when factors that promote selfrenewal, such as feeder cells and $\beta F G F$, are removed from the culture medium $(31,32)$, albeit at a low frequency. Research should therefore focus on selection and enrichment of specific cell lineages toward directed differentiation. Improvement of germ cell differentiation, evidenced by enhanced expression of pre-meiotic and meiotic germ cell-specific genes, was observed in iPSCs derived from embryoid bodies (EBs) (33). Selection of germ cells from these EBs may be achieved by a simple density gradient procedure (34). Furthermore, injection of testicular cells and iPSCs into the dorsal skin of mice led to reconstitution of seminiferous tubules, with iPSC-derived germ cells settling on basement membranes of reconstituted tubules $(33,35)$. While iPSCs are most commonly derived from skin fibroblasts, iPSCs derived from adult mouse hepatocytes can also give rise to presumptive germ cells (36). iPSCs can therefore produce candidate male germ cells in vitro, independently of their origin. Moreover, iPSCs transplanted into the seminiferous tubules of $\mathrm{W} / \mathrm{W}^{\mathrm{v}}$ mice, lacking endogenous spermatogenesis, are able to undergo their own spermatogenesis and generate offspring after ICSI followed by embryo transfer (37). Although most transplanted mice died and some pups presented 
with tumors, this study demonstrates the potential of germ-like cells in fertility recovery.

\section{Studies on human iPSCs}

During spontaneous iPSC differentiation, a small population of male germ cells, including round spermatid-like cells, was observed $(38,39)$, suggesting the possibility of achieving differentiation and maturation of iPSCs into spermatozoa. Panula (40) showed that human iPSCs grown in a medium enriched with bone morphogenic protein 4 (BMP4) can differentiate into PGCs, albeit at a low efficiency of just 5\%. The deleted in azoospermia (DAZ) gene family and human deleted in azoospermia-like (DAZL) are involved in PGC formation, whereas the $\mathrm{Y}$ chromosome homolog DAZ and closely related BOULE promote later stages of meiosis and development of haploid gametes (41). Indeed, meiosis was entered when DAZ family proteins (DAZL, BOULE, and DAZ) were overexpressed and some PGCs continued their maturation into haploid cells, showing an acrosomal complex identical to that of spermatids (40). Through similar experiments, Eguizabal et al. (31) obtained haploid cells using a medium enriched with retinoic acid, a differentiating factor acting as a trigger for meiosis. Haploid male germ line acrosin-positive cells were consistently obtained, without overexpression of any developmentally related genes, from human iPSCs of different origin (fibroblasts, keratinocytes, or cord blood), suggesting independence from the epigenetic memory of reprogramed somatic cells.

So far, no mature sperm have been obtained in vitro and there are still many unknowns concerning autocrine, paracrine, and endocrine hormonal factors, as well as the nutritional control of germ cell maturation. In this regard, attempts to differentiate germ cells from human iPSCs, with key factors used to direct them into germ cell lineage, are summarized in Table $\mathbf{1}$.

\section{iPSC DIFFERENTIATION INTO FEMALE GAMETE LINEAGE}

While numerous studies have demonstrated the ability of ESCs to differentiate into female germ cells, with some groups reporting formation of follicle-like structures and oocyte-like cells (44-53), only three studies in animals have investigated the potential of iPSCs to differentiate into female germ cell lineage. Among germ cells derived from iPSCs, several have shown the potential to differentiate into oocyte-like cells. When iPSCs from male or female animals were cultured in EB formations, some round-shaped cells were found to express mouse vasa homolog gene (Mvh), an early PGC reporter. In addition, these round-shaped cells showed expression of early oocyte-like markers (54), demonstrating the capacity of iPSCs to differentiate into female germ cell lineage. The ability of iPSCs to differentiate into oogonia was evidenced by expression of oocyte markers Zp2 and Zp3 after exposure of iPSCs to RA, although at a smaller proportion than in differentiation into spermatogonial lineage $(55,56)$.

\section{TECHNICAL LIMITATIONS}

Since the discovery of PSCs in human beings, scientists have looked at the possibility of using this source of special cells to regenerate tissue and organs, with a considerably reduced risk of an immune response. Despite the great promise of iPSC technology, there are still barriers to overcome before these cells can be used in a clinical context.
The gold standard technique utilized to reprogram somatic cells is the inducible lentiviral vector that reaches $2 \%$ efficiency (57). While it shows relatively good efficacy, the lentiviral vector requires genomic integration to reprogram somatic cells. Retroviral vectors contain transcription factors that are potentially oncogenic, especially oncogene $c-M Y C$, although it has been shown to be dispensable for iPSC generation (18). However, exogenous OCT4 (58), KLF4 (59), and NANOG (60) can also cause teratoma formation. Indeed transplantation of a single undifferentiated cell might result in tumor formation or proliferation of inappropriate cell types. Retroviral vectors are silenced after reprograming, but slight reactivation has been observed during differentiation, although this did not appear to have a major impact on germline-directed differentiation of iPSCs. Unfortunately, selection of iPSCs with a low viral copy number is insufficient to eliminate the oncogenic risk. Besides tumor formation, there is a risk of genetic recombination or insertion mutagenesis, which can affect cell differentiation due to random vector integration into the genome. Even for in vitro applications of iPSCs, such as disease modeling, drug screening, or toxicology tests, re-expression of exogenous factors resulting in genome modification could disturb the properties of cells and yield biased results. Therefore, production of iPSCs with minimal or no genetic modifications is essential. Maintenance of a stable karyotype (61) and elimination of the risk of tumor formation required for clinical use of iPSC lines are challenging areas in iPSC technology.

\section{STRATEGIES TO ENSURE SAFETY ASPECTS}

Induced pluripotent stem cell lines carry the risk of mutagenesis. Strategies to overcome this barrier and eventually offer the possibility of potential application in humans should be implemented. Excisable Lentiviral (62) and transposon (63) vectors deliver reasonably good reprograming efficiency $(0.1-1 \%)$, but require constant and intensive screening of excised cell lines. Other non-integrating methods, such as repeat application of plasmid (64), episomal, or adenovirus (65) vectors with transient expression, have the disadvantage of low efficiency $(0.001 \%)$ and occasional genomic integration. The most recent technologies employ DNA-free methods to reprogram cells. Use of Sendai virus (66), modified mRNA (67), micro-RNA (68), or proteins (69) that modulate the reprograming process could be a powerful approach to generate more efficient and safer iPSCs. The modified mRNA method in particular shows encouraging results, with efficacy reaching $4.4 \%$. In addition, modified mRNAs bypass innate antiviral responses, have a fast kinetic response and are applicable to a range of tissue engineering tasks (68).

Finally, reprograming technology allows avoidance of the stem cell stage by direct reprograming, converting endogenous cells directly into desired cell types by gene transfer of defined factors, as has been demonstrated in hepatocyte (70), neuron (71), and cardiomyocyte differentiation (72). Direct reprograming has the principal advantage of drastically reducing the risk of contamination with undifferentiated cells, and hence the risk of transplanting those cells $(73,74)$. While there appears to be a consensus on the need to exclude undifferentiated cells, the level of differentiation required for clinical use of iPSCs is still an open question. 


\section{CONCLUSION}

Numerous pre-clinical trials (shown in Table A1 in Appendix) have convincingly shown that iPSCs can be differentiated into cells with the capacity for tissue or cell repair, but there is still a long way to go before all differentiation issues are adequately addressed. Besides demonstrating full and safe functioning, development of clinical-grade iPSCs has to meet the safety requirements of regulatory bodies, namely being virus integration-free (62), respecting xeno free conditions (75), using of a synthetic matrix (76), and ultimately applying GMP-compliant reprograming technology. Meanwhile, iPSCs provide a useful platform for understanding diseases and establishing the efficacy and toxicity of new therapies. In reproductive medicine, they represent a tool to study human germ cell development and fertility defects, and offer perspectives to restore fertility in patients presenting with irreversible infertility due to gonadotoxic treatment or genetic background. As such, iPSCs show great promise and will undoubtedly be the subject of active research in the coming years.

\section{ACKNOWLEDGMENTS}

The authors thank Mira Hryniuk, B.A., for reviewing the English language of this manuscript.

\section{REFERENCES}

1. Thomson JA, Itskovitz-Eldor J, Shapiro SS, Waknitz MA, Swiergiel JJ, Marshall VS, et al. Embryonic stem cell lines derived from human blastocysts. Science (1998) 282(5391):1145-7. doi:10.1126/science.282.5391.1145

2. Sermon KD, Simon C, Braude P, Viville S, Borstlap J, Veiga A. Creation of a registry for human embryonic stem cells carrying an inherited defect: joint collaboration between ESHRE and hESCreg. Hum Reprod (2009) 24(7):1556-60. doi:10.1093/humrep/dep062

3. Swijnenburg RJ, Schrepfer S, Cao F, Pearl JI, Xie X, Connolly AJ, et al. In vivo imaging of embryonic stem cells reveals patterns of survival and immune rejection following transplantation. Stem Cells Dev (2008) 17(6):1023-9. doi:10.1089/scd.2008.0091

4. Swijnenburg RJ, Schrepfer S, Govaert JA, Cao F, Ransohoff K, Sheikh AY, et al. Immunosuppressive therapy mitigates immunological rejection of human embryonic stem cell xenografts. Proc Natl Acad Sci U S A (2008) 105(35):12991-6. doi:10.1073/pnas.0805802105

5. Takahashi K, Yamanaka S. Induction of pluripotent stem cells from mouse embryonic and adult fibroblast cultures by defined factors. Cell (2006) 126(4):663-76. doi:10.1016/j.cell.2006.07.024

6. Niwa H, Miyazaki J, Smith AG. Quantitative expression of Oct-3/4 defines differentiation, dedifferentiation or self-renewal of ES cells. Nat Genet (2000) 24(4):372-6. doi:10.1038/74199

7. Avilion AA, Nicolis SK, Pevny LH, Perez L, Vivian N, Lovell-Badge R. Multipotent cell lineages in early mouse development depend on SOX2 function. Genes Dev (2003) 17(1):126-40. doi:10.1101/gad.224503

8. Cartwright P, McLean C, Sheppard A, Rivett D, Jones K, Dalton S. LIF/STAT3 controls ES cell self-renewal and pluripotency by a Myc-dependent mechanism. Development (2005) 132(5):885-96. doi:10.1242/dev.01670

9. Li Y, McClintick J, Zhong L, Edenberg HJ, Yoder MC, Chan RJ. Murine embryonic stem cell differentiation is promoted by SOCS-3 and inhibited by the zinc finger transcription factor Klf4. Blood (2005) 105(2):635-7. doi:10.1182/blood-2004-07-2681

10. Okita K, Ichisaka T, Yamanaka S. Generation of germline-competent induced pluripotent stem cells. Nature (2007) 448(7151):313-7. doi:10.1038/ nature 05934

11. Takahashi K, Tanabe K, Ohnuki M, Narita M, Ichisaka T, Tomoda K, et al. Induction of pluripotent stem cells from adult human fibroblasts by defined factors. Cell (2007) 131(5):861-72. doi:10.1016/j.cell.2007.11.019

12. Taapken SM, Nisler BS, Newton MA, Sampsell-Barron TL, Leonhard KA, McIntire EM, et al. Karotypic abnormalities in human induced pluripotent stem cells and embryonic stem cells. Nat Biotechnol (2011) 29(4):313-4. doi:10.1038/nbt.1835
13. Nichols J, Zevnik B, Anastassiadis K, Niwa H, Klewe-Nebenius D, Chambers I, et al. Formation of pluripotent stem cells in the mammalian embryo depends on the POU transcription factor Oct4. Cell (1998) 95(3):379-91. doi:10.1016/S0092-8674(00)81769-9

14. Lee G, Papapetrou EP, Kim H, Chambers SM, Tomishima MJ, Fasano CA, et al. Modelling pathogenesis and treatment of familial dysautonomia using patientspecific iPSCs. Nature (2009) 461(7262):402-6. doi:10.1038/nature08320

15. Anderson SL, Qiu J, Rubin BY. EGCG corrects aberrant splicing of IKAP mRNA in cells from patients with familial dysautonomia. Biochem Biophys Res Commun (2003) 310(2):627-33. doi:10.1016/j.bbrc.2003.09.019

16. Itzhaki I, Maizels L, Huber I, Gepstein A, Arbel G, Caspi O, et al. Modeling of catecholaminergic polymorphic ventricular tachycardia with patientspecific human-induced pluripotent stem cells. J Am Coll Cardiol (2012) 60(11):990-1000. doi:10.1016/j.jacc.2012.02.066

17. Hanna J, Wernig M, Markoulaki S, Sun CW, Meissner A, Cassady JP, et al. Treatment of sickle cell anemia mouse model with iPS cells generated from autologous skin. Science (2007) 318(5858):1920-3. doi:10.1126/science.1152092

18. Wernig M, Meissner A, Cassady JP, Jaenisch R. c-Myc is dispensable for direct reprogramming of mouse fibroblasts. Cell Stem Cell (2008) 2(1):10-2. doi:10.1016/j.stem.2007.12.001

19. Wernig M, Zhao JP, Pruszak J, Hedlund E, Fu D, Soldner F, et al. Neurons derived from reprogrammed fibroblasts functionally integrate into the fetal brain and improve symptoms of rats with Parkinson's disease. Proc Natl Acad Sci U S A (2008) 105(15):5856-61. doi:10.1073/pnas.0801677105

20. Li W, Wang X, Fan W, Zhao P, Chan YC, Chen S, et al. Modeling abnormal early development with induced pluripotent stem cells from aneuploid syndromes. Hum Mol Genet (2012) 21(1):32-45. doi:10.1093/hmg/ddr435

21. Rodrigo SF, van Ramshorst J, Hoogslag GE, Boden H, Velders MA, Cannegieter SC, et al. Intramyocardial injection of autologous bone marrow-derived ex vivo expanded mesenchymal stem cells in acute myocardial infarction patients is feasible and safe up to 5 years of follow-up. J Cardiovasc Transl Res (2013) 6(5):816-25. doi:10.1007/s12265-013-9507-7

22. Zhang Z, Lin H, Shi M, Xu R, Fu J, Lv J, et al. Human umbilical cord mesenchymal stem cells improve liver function and ascites in decompensated liver cirrhosis patients. J Gastroenterol Hepatol (2012) 27(Suppl 2):112-20. doi:10.1111/j.1440-1746.2011.07024.x

23. Wang L, Zhao S, Mao H, Zhou L, Wang ZJ, Wang HX. Autologous bone marrow stem cell transplantation for the treatment of type 2 diabetes mellitus. Chin Med J (Engl) (2011) 124(22):3622-8. doi:10.3760/cma.j.issn.0366-6999.2011. 22.005

24. Kunisada Y, Tsubooka-Yamazoe N, Shoji M, Hosoya M. Small molecules induce efficient differentiation into insulin-producing cells from human induced pluripotent stem cells. Stem Cell Res (2012) 8(2):274-84. doi:10.1016/j.scr. 2011.10.002

25. McLaren A. Meiosis and differentiation of mouse germ cells. Symp Soc Exp Biol (1984) 38:7-23.

26. Mamsen LS, Brøchner CB, Byskov AG, Møllgard K. The migration and loss of human primordial germ stem cells from the hind gut epithelium towards the gonadal ridge. Int J Dev Biol (2012) 56(10-12):771-8. doi:10.1387/ijdb. $120202 \mathrm{~lm}$

27. Surani MA, Hayashi K, Hajkova P. Genetic and epigenetic regulators of pluripotency. Cell (2007) 128(4):747-62. doi:10.1016/j.cell.2007.02.010

28. Ohinata Y, Payer B, O'Carroll D, Ancelin K, Ono Y, Sano M, et al. Blimp1 is a critical determinant of the germ cell lineage in mice. Nature (2005) 436(7048):207-13. doi:10.1038/nature03813

29. Yabuta Y, Kurimoto K, Ohinata Y, Seki Y, Saitou M. Gene expression dynamics during germline specification in mice identified by quantitative single-cell gene expression profiling. Biol Reprod (2006) 75(5):705-16. doi:10.1095/biolreprod. 106.053686

30. Li C, Yu H, Ma Y, Shi G, Jiang J, Gu J, et al. Germline-competent mouseinduced pluripotent stem cell lines generated on human fibroblasts without exogenous leukemia inhibitory factor. PLoS One (2009) 4(8):e6724. doi:10.1371/journal.pone.0006724

31. Eguizabal C, Montserrat N, Vassena R, Barragan M, Garreta E, Garcia-Quevedo $\mathrm{L}$, et al. Complete meiosis from human induced pluripotent stem cells. Stem Cells (2011) 29(8):1186-95. doi:10.1002/stem.672

32. Hirai H, Firpo M, Kikyo N. Establishment of LIF-dependent human iPS cells closely related to basic FGF-dependent authentic iPS cells. PLoS One (2012) 7(6):e39022. doi:10.1371/journal.pone.0039022 
33. Yang S, Bo J, Hu H, Guo X, Tian R, Sun C, et al. Derivation of male germ cells from induced pluripotent stem cells in vitro and in reconstituted seminiferous tubules. Cell Prolif (2012) 45(2):91-100. doi:10.1111/j.1365-2184.2012. 00811.x

34. Saiti D, Lacham-Kaplan O. Density gradients for the isolation of germ cells from embryoid bodies. Reprod Biomed Online (2008) 16(5):730-40. doi:10.1016/S1472-6483(10)60489-0

35. Zhu Y, Hu HL, Li P, Yang S, Zhang W, Ding H, et al. Generation of male germ cells from induced pluripotent stem cells (iPS cells): an in vitro and in vivo study. Asian J Androl (2012) 14(4):574-9. doi:10.1038/aja.2012.3

36. Aoi T, Yae K, Nakagawa M, Ichisaka T, Okita K, Takahashi K, et al. Generation of pluripotent stem cells from adult mouse liver and stomach cells. Science (2008) 321(5889):699-702. doi:10.1126/science.1154884

37. Hayashi K, Ohta H, Kurimoto K, Aramaki S, Saitou M. Reconstitution of the mouse germ cell specification pathway in culture by pluripotent stem cells. Cell (2011) 146(4):519-32. doi:10.1016/j.cell.2011.06.052

38. Easley CA IV, Phillips BT, McGuire MM, Barringer JM, Valli H, Hermann BP, et al. Direct differentiation of human pluripotent stem cells into haploid spermatogenic cells. Cell Rep (2012) 2(3):440-6. doi:10.1016/j.celrep.2012.07. 015

39. Medrano JV, Ramathal C, Nguyen HN, Simon C, Reijo Pera RA. Divergent RNA-binding proteins, DAZL and VASA, induce meiotic progression in human germ cells derived in vitro. Stem Cells (2012) 30(3):441-51. doi:10.1002/stem.1012

40. Panula S, Medrano JV, Kee K, Bergström R, Nguyen HN, Byers B, et al. Human germ cell differentiation from fetal- and adult-derived induced pluripotent stem cells. Hum Mol Genet (2011) 20(4):752-62. doi:10.1093/hmg/ddq520

41. Kee K, Angeles VT, Flores M, Nguyen HN, Reijo Pera RA. Human DAZL, DAZ and BOULE genes modulate primordial germ-cell and haploid gamete formation. Nature (2009) 462(7270):222-5. doi:10.1038/nature08562

42. Park TS, Galic Z, Conway AE, Lindgren A, van Handel BJ, Magnusson M, et al. Derivation of primordial germ cells from human embryonic and induced pluripotent stem cells is significantly improved by coculture with human fetal gonadal cells. Stem Cells (2009) 27(4):783-95. doi:10.1002/stem.13

43. Ma Y, Li C, Gu J, Tang F, Li C, Li P, et al. Aberrant gene expression profiles in pluripotent stem cells induced from fibroblasts of a Klinefelter syndrome patient. J Biol Chem (2012) 287(46):38970-9. doi:10.1074/jbc.M112.380204

44. Hübner K, Fuhrmann G, Christenson LK, Kehler J, Reinbold R, De La Fuente R, et al. Derivation of oocytes from mouse embryonic stem cells. Science (2003) 300(5623):1251-6. doi:10.1126/science.1083452

45. Lacham-Kaplan O, Chy H, Trounson A. Testicular cell conditioned medium supports differentiation of embryonic stem cells into ovarian structures containing oocytes. Stem Cells (2006) 24:266-73. doi:10.1634/stemcells.2005-0204

46. Novak I, Lightfoot DA, Wang H, Eriksson A, Mahdy E, Höög C. Mouse embryonic stem cells form follicle-like ovarian structures but do not progress through meiosis. Stem Cells (2006) 24(8):1931-6. doi:10.1634/stemcells.2005-0520

47. Qing T, Shi Y, Qin H, Ye X, Wei W, Liu H, et al. Induction of oocyte-like cells from mouse embryonic stem cells by co-culture with ovarian granulosa cells. Differentiation (2007) 75(10):902-11. doi:10.1111/j.1432-0436.2007.00181.x

48. Chen HF, Kuo HC, Chien CL, Shun CT, Yao YL, Ip PL, et al. Derivation, characterization and differentiation of human embryonic stem cells: comparing serum-containing versus serum-free media and evidence of germ cell differentiation. Hum Reprod (2007) 22(2):567-77. doi:10.1093/humrep/del412

49. Aflatoonian B, Ruban L, Jones M, Aflatoonian R, Fazeli A, Moore HD. In vitro post-meiotic germ cell development from human embryonic stem cells. Hum Reprod (2009) 24(12):3150-9. doi:10.1093/humrep/dep334

50. Nicholas CR, Haston KM, Grewall AK, Longacre TA, Reijo Pera RA. Transplantation directs oocyte maturation from embryonic stem cells and provides a therapeutic strategy for female infertility. Hum Mol Genet (2009) 18(22):4376-89. doi:10.1093/hmg/ddp393

51. Salvador LM, Silva CP, Kostetskii I, Radice GL, Strauss JF III. The promoter of the oocyte-specific gene, Gdf9, is active in population of cultured mouse embryonic stem cells with an oocyte-like phenotype. Methods (2008) 45(2):172-81. doi:10.1016/j.ymeth.2008.03.004

52. Hu Y, Sun J, Wang J, Wang L, Bai Y, Yu M, et al. Characterization of female germlike cells derived from mouse embryonic stem cells through expression of GFP under the control of Figla promoter. J Cell Biochem (2012) 113(4):1111-21. doi:10.1002/jcb.24044
53. Wang L, Cao J, Ji P, Zhang D, Ma L, Dym M, et al. Oocyte-like cells induced from mouse spermatogonial stem cells. Cell Biosci (2012) 2(1):27. doi:10.1186/2045-3701-2-27

54. Imamura M, Aoi T, Tokumasu A, Mise N, Abe K, Yamanaka S, et al. Induction of primordial germ cells from mouse induced pluripotent stem cells derived from adult hepatocytes. Mol Reprod Dev (2010) 77(9):802-11. doi:10.1002/ mrd.21223

55. Hayashi K, Ogushi S, Kurimoto K, Shimamoto S, Ohta H, Saitou M. Offspring from oocytes derived from in vitro primordial germ cell-like cells in mice. Science (2012) 338(6109):971-5. doi:10.1126/science.1226889

56. Niu Z, Hu Y, Chu Z, Yu M, Bai Y, Wang L, et al. Germ-like cell differentiation from induced pluripotent stem cells (iPSCs). Cell Biochem Funct (2013) 31(1):12-9. doi:10.1002/cbf.2924

57. Maherali N, Ahfeldt T, Rigamonti A, Utikal J, Cowan C, Hochedlinger K. A highefficiency system for the generation and study of human induced pluripotent stem cells. Cell Stem Cell (2008) 3(3):340-5. doi:10.1016/j.stem.2008.08.003

58. Hochedlinger K, Yamada Y, Beard C, Jaenisch R. Ectopic expression of Oct-4 blocks progenitor-cell differentiation and causes dysplasia in epithelial tissues. Cell (2005) 121(3):465-77. doi:10.1016/j.cell.2005.02.018

59. Foster KW, Liu Z, Nail CD, Li X, Fitzgerald TJ, Bailey SK, et al. Induction of KLF4 in basal keratinocytes blocks the proliferation-differentiation switch and initiates squamous epithelial dysplasia. Oncogene (2005) 24(9):1491-500. doi:10.1038/sj.onc. 1208307

60. Grad I, Hibaoui Y, Jaconi M, Chicha L, Bergström-Tengzelius R, Sailani MR, et al. NANOG priming before full reprogramming may generate germ cell tumours. Eur Cell Mater (2011) 22:258-74.

61. Carpenter MK, Frey-Vasconcells J, Rao MS. Developing safe therapies from human pluripotent stem cells. Nat Biotechnol (2009) 27(7):606-13. doi:10. 1038/nbt0709-606

62. Sommer CA, Sommer AG, Longmire TA, Christodoulou C, Thomas DD, Gostissa M, et al. Excision of reprogramming transgenes improves the differentiation potential of iPS cells generated with a single excisable vector. Stem Cells (2010) 28(1):64-74. doi:10.1002/stem.255

63. Woltjen K, Michael IP, Mohseni P, Desai R, Mileikovsky M, Hämäläinen R, et al. piggyBac transposition reprograms fibroblasts to induced pluripotent stem cells. Nature (2009) 458(7239):766-70. doi:10.1038/nature07863

64. Okita K, Nakagawa M, Hyenjong H, Ichisaka T, Yamanaka S. Generation of mouse induced pluripotent stem cells without viral vectors. Science (2008) 322(5903):949-53. doi:10.1126/science.1164270

65. Stadtfeld M, Nagaya M, Utikal J, Weir G, Hochedlinger K. Induced pluripotent stem cells generated without viral integration. Science (2008) 322(5903):945-9. doi:10.1126/science.1162494

66. Fusaki N, Ban H, Nishiyama A, Saeki K, Hasegawa M. Efficient induction of transgene-free human pluripotent stem cells using a vector based on Sendai virus, an RNA virus that does not integrate into the host genome. Proc Jpn Acad Ser B Phys Biol Sci (2009) 85(8):348-62. doi:10.2183/pjab.85.348

67. Warren L, Manos PD, Ahfeldt T, Loh YH, Li H, Lau F, et al. Highly efficient reprogramming to pluripotency and directed differentiation of human cells with synthetic modified mRNA. Cell Stem Cell (2010) 7(5):618-30. doi:10.1016/j.stem.2010.08.012

68. Miyoshi N, Ishii H, Nagano H, Haraguchi N, Dewi DL, Kano Y, et al. Reprogramming of mouse and human cells to pluripotency using mature microRNAs. Cell Stem Cell (2011) 8(6):633-8. doi:10.1016/j.stem.2011.05.001

69. Kaji K, Norrby K, Paca A, Mileikovsky M, Mohseni P, Woltjen K. Virus-free induction of pluripotency and subsequent excision of reprogramming factors. Nature (2009) 458(7239):771-5. doi:10.1038/nature07864

70. Sekiya S, Suzuki A. Direct conversion of mouse fibroblasts to hepatocytelike cells by defined factors. Nature (2011) 475(7356):390-3. doi:10.1038/ nature 10263

71. Caiazzo M, Dell'Anno MT, Dvoretskova E, Lazarevic D, Taverna S, Leo D, et al. Direct generation of functional dopaminergic neurons from mouse and human fibroblasts. Nature (2011) 476(7359):224-7. doi:10.1038/nature10284

72. Inagawa K, Miyamoto K, Yamakawa H, Muraoka N, Sadahiro T, Umei T, et al. Induction of cardiomyocyte-like cells in infarct hearts by gene transfer of Gata4, Mef2c, and Tbx5. Circ Res (2012) 111(9):1147-56. doi:10.1161/CIRCRESAHA. 112.271148

73. Zhou H, Jin Z, Liu J, Yu S, Cui Q, Yi D. Mesenchymal stem cells might be used to induce tolerance in heart transplantation. Med Hypotheses (2008) 70(4):785-7. doi:10.1016/j.mehy.2007.08.010 
74. Song K, Nam YJ, Luo X, Qi X, Tan W, Huang GN, et al. Heart repair by reprogramming non-myocytes with cardiac transcription factors. Nature (2012) 485(7400):599-604. doi:10.1038/nature11139

75. Rodríguez-Pizà I, Richaud-Patin Y, Vassena R, González F, Barrero MJ, Veiga A, et al. Reprogramming of human fibroblasts to induced pluripotent stem cells under xeno-free conditions. Stem Cells (2010) 28(1):36-44. doi:10.1002/stem. 248

76. Sun N, Panetta NJ, Gupta DM, Wilson KD, Lee A, Jia F, et al. Feeder-free derivation of induced pluripotent stem cells from adult human adipose stem cells. Proc Natl Acad Sci U S A (2009) 106(37):15720-5. doi:10.1073/pnas. 0908450106

77. Soldner F, Hockemeyer D, Beard C, Gao Q, Bell GW, Cook EG, et al. Parkinson's disease patient-derived induced pluripotent stem cells free of viral reprogramming factors. Cell (2009) 136(5):964-77. doi:10.1016/j.cell.2009.02.013

78. Panicker LM, Miller D, Park TS, Patel B, Azevedo JL, Awad O, et al. Induced pluripotent stem cell model recapitulates pathologic hallmarks of Gaucher disease. Proc Natl Acad Sci U S A (2012) 109(44):18054-9. doi:10.1073/pnas. 1207889109

79. Maehr R, Chen S, Snitow M, Ludwig T, Yagasaki L, Goland R, et al. Generation of pluripotent stem cells from patients with type 1 diabetes. Proc Natl Acad Sci U S A (2009) 106(37):15768-73. doi:10.1073/pnas.0906894106

80. Somers A, Jean JC, Sommer CA, Omari A, Ford CC, Mills JA, et al. Generation of transgene-free lung disease-specific human induced pluripotent stem cells using a single excisable lentiviral stem cell cassette. Stem Cells (2010) 28(10):1728-40. doi:10.1002/stem.495

81. Rashid ST, Corbineau S, Hannan N, Marciniak SJ, Miranda E, Alexander G, et al. Modeling inherited metabolic disorders of the liver using human induced pluripotent stem cells. J Clin Invest (2010) 120(9):3127-36. doi:10. $1172 /$ JCI 43122

82. Ghodsizadeh A, Taei A, Totonchi M, Seifinejad A, Gourabi H, Pournasr B, et al. Generation of liver disease-specific induced pluripotent stem cells along with efficient differentiation to functional hepatocyte-like cells. Stem Cell Rev (2010) 6(4):622-32. doi:10.1007/s12015-010-9189-3

83. Tolar J, Xia L, Riddle MJ, Lees CJ, Eide CR, McElmurry RT, et al. Induced pluripotent stem cells from individuals with recessive dystrophic epidermolysis bullosa. J Invest Dermatol (2011) 131(4):848-56. doi:10.1038/jid.2010.346

84. Lemonnier T, Blanchard S, Toli D, Roy E, Bigou S, Froissart R, et al. Modeling neuronal defects associated with a lysosomal disorder using patient-derived induced pluripotent stem cells. Hum Mol Genet (2011) 20(18):3653-66. doi: $10.1093 / \mathrm{hmg} / \mathrm{ddr} 285$

85. Trilck M, Hübner R, Seibler P, Klein C, Rolfs A, Frech MJ. Niemann-Pick type $\mathrm{C} 1$ patient-specific induced pluripotent stem cells display disease specific hallmarks. Orphanet J Rare Dis (2013) 8(1):144. doi:10.1186/1750-1172-8-144

86. Schneider BL, Seehus CR, Capowski EE, Aebischer P, Zhang SC, Svendsen CN. Over-expression of alpha-synuclein in human neural progenitors leads to specific changes in fate and differentiation. Hum Mol Genet (2007) 16(6):651-66. doi: $10.1093 / \mathrm{hmg} / \mathrm{ddm} 008$

87. Hargus G, Cooper O, Deleidi M, Levy A, Lee K, Marlow E, et al. Differentiated Parkinson patient-derived induced pluripotent stem cells grow in the adult rodent brain and reduce motor asymmetry in Parkinsonian rats. Proc Natl Acad Sci U S A (2010) 107(36):15921-6. doi:10.1073/pnas.1010209107

88. Swistowski A, Peng J, Liu Q, Mali P, Rao MS, Cheng L, et al. Efficient generation of functional dopaminergic neurons from human induced pluripotent stem cells under defined conditions. Stem Cells (2010) 28(10):1893-904. doi:10.1002/stem.499

89. Seibler P, Graziotto J, Jeong H, Simunovic F, Klein C, Krainc D. Mitochondrial Parkin recruitment is impaired in neurons derived from mutant PINK1 induced pluripotent stem cells. J Neurosci (2011) 31(16):5970-6. doi:10.1523/JNEUROSCI.4441-10.2011

90. Devine MJ, Ryten M, Vodicka P, Thomson AJ, Burdon T, Houlden H, et al. Parkinson's disease induced pluripotent stem cells with triplication of the $\alpha$ synuclein locus. Nat Commun (2011) 2:440. doi:10.1038/ncomms1453

91. Nguyen HN, Byers B, Cord B, Shcheglovitov A, Byrne J, Gujar P, et al. LRRK2 mutant iPSC-derived DA neurons demonstrate increased susceptibility to oxidative stress. Cell Stem Cell (2011) 8(3):267-80. doi:10.1016/j.stem.2011. 01.013

92. Park IH, Arora N, Huo H, Maherali N, Ahfeldt T, Shimamura A, et al. Disease-specific induced pluripotent stem cells. Cell (2008) 134(5):877-86. doi:10.1016/j.cell.2008.07.041
93. Zhang N, An MC, Montoro D, Ellerby LM. Characterization of human huntington's disease cell model from induced pluripotent stem cells. PLoS Curr (2010) 2:RRN1193. doi:10.1371/currents.RRN1193

94. Dimos JT, Rodolfa KT, Niakan KK, Weisenthal LM, Mitsumoto H, Chung $\mathrm{W}$, et al. Induced pluripotent stem cells generated from patients with ALS can be differentiated into motor neurons. Science (2008) 321(5893):1218-21. doi:10.1126/science.1158799

95. Mitne-Neto M, Machado-Costa M, Marchetto MC, Bengtson MH, Joazeiro CA, Tsuda $\mathrm{H}$, et al. Downregulation of VAPB expression in motor neurons derived from induced pluripotent stem cells of ALS8 patients. Hum Mol Genet (2011) 20(18):3642-52. doi:10.1093/hmg/ddr284

96. Marchetto MC, Carromeu C, Acab A, Yu D, Yeo GW, Mu Y, et al. A model for neural development and treatment of Rett syndrome using human induced pluripotent stem cells. Cell (2010) 143(4):527-39. doi:10.1016/j.cell. 2010.10.016

97. Cheung AY, Horvath LM, Grafodatskaya D, Pasceri P, Weksberg R, Hotta A, et al. Isolation of MECP2-null Rett Syndrome patient hiPS cells and isogenic controls through X-chromosome inactivation. Hum Mol Genet (2011) 20(11):2103-15. doi: $10.1093 / \mathrm{hmg} / \mathrm{ddr} 093$

98. Kim KY, Hysolli E, Park IH. Neuronal maturation defect in induced pluripotent stem cells from patients with Rett syndrome. Proc Natl Acad Sci U S A (2011) 108(34):14169-74. doi:10.1073/pnas.1018979108

99. Ebert AD, Yu J, Rose FF Jr, Mattis VB, Lorson CL, Thomson JA, et al. Induced pluripotent stem cells from a spinal muscular atrophy patient. Nature (2009) 457(7227):277-80. doi:10.1038/nature07677

100. Chang T, Zheng W, Tsark W, Bates S, Huang H, Lin RJ, et al. Brief report: phenotypic rescue of induced pluripotent stem cell-derived motoneurons of a spinal muscular atrophy patient. Stem Cells (2011) 29(12):2090-3. doi:10.1002/stem.749

101. Chamberlain SJ, Chen PF, Ng KY, Bourgois-Rocha F, Lemtiri-Chlieh F, Levine ES, et al. Induced pluripotent stem cell models of the genomic imprinting disorders Angelman and Prader-Willi syndromes. Proc Natl Acad Sci U S A (2010) 107(41):17668-73. doi:10.1073/pnas.1004487107

102. Yang J, Cai J, Zhang Y, Wang X, Li W, Xu J, et al. Induced pluripotent stem cells can be used to model the genomic imprinting disorder Prader-Willi syndrome. J Biol Chem (2010) 285(51):40303-11. doi:10.1074/jbc.M110.183392

103. Liu J, Verma PJ, Evans-Galea MV, Delatycki MB, Michalska A, Leung J, et al. Generation of induced pluripotent stem cell lines from Friedreich ataxia patients. Stem Cell Rev (2011) 7(3):703-13. doi:10.1007/s12015-0109210-x

104. Brennand KJ, Simone A, Jou J, Gelboin-Burkhart C, Tran N, Sangar S, et al. Modelling schizophrenia using human induced pluripotent stem cells. Nature (2011) 473(7346):221-5. doi:10.1038/nature09915

105. Koch P, Breuer P, Peitz M, Jungverdorben J, Kesavan J, Poppe D, et al. Excitationinduced ataxin-3 aggregation in neurons from patients with Machado-Joseph disease. Nature (2011) 480(7378):543-6. doi:10.1038/nature10671

106. Jang J, Kang HC, Kim HS, Kim JY, Huh YJ, Kim DS, et al. Induced pluripotent stem cell models from X-linked adrenoleukodystrophy patients. Ann Neurol (2011) 70(3):402-9. doi:10.1002/ana.22486

107. Yagi T, Ito D, Okada Y, Akamatsu W, Nihei Y, Yoshizaki T, et al. Modeling familial Alzheimer's disease with induced pluripotent stem cells. Hum Mol Genet (2011) 20(23):4530-9. doi:10.1093/hmg/ddr394

108. Israel MA, Yuan SH, Bardy C, Reyna SM, Mu Y, Herrera C, et al. Probing sporadic and familial Alzheimer's disease using induced pluripotent stem cells. Nature (2012) 482(7384):216-20. doi:10.1038/nature10821

109. Meyer JS, Howden SE, Wallace KA, Verhoeven AD, Wright LS, Capowski EE, et al. Optic vesicle-like structures derived from human pluripotent stem cells facilitate a customized approach to retinal disease treatment. Stem Cells (2011) 29(8):1206-18. doi:10.1002/stem.674

110. Tucker BA, Scheetz TE, Mullins RF, DeLuca AP, Hoffmann JM, Johnston RM, et al. Exome sequencing and analysis of induced pluripotent stem cells identify the cilia-related gene male germ cell-associated kinase (MAK) as a cause of retinitis pigmentosa. Proc Natl Acad Sci U S A (2011) 108(34):E569-76. doi:10.1073/pnas.1108918108

111. Jin ZB, Okamoto S, Xiang P, Takahashi M. Integration-free induced pluripotent stem cells derived from retinitis pigmentosa patient for disease modeling. Stem Cells Transl Med (2012) 1(6):503-9. doi:10.5966/sctm.2012-0005

112. Zahabi A, Shahbazi E, Ahmadieh H, Hassani SN, Totonchi M, Taei A, et al. A new efficient protocol for directed differentiation of retinal pigmented epithelial 
cells from normal and retinal disease induced pluripotent stem cells. Stem Cells $\operatorname{Dev}$ (2012) 21(12):2262-72. doi:10.1089/scd.2011.0599

113. Raya A, Rodríguez-Pizà I, Guenechea G, Vassena R, Navarro S, Barrero MJ, et al. Disease-corrected haematopoietic progenitors from Fanconi anaemia induced pluripotent stem cells. Nature (2009) 460(7251):53-9. doi:10.1038/ nature 08129

114. Ye L, Chang JC, Lin C, Sun X, Yu J, Kan YW. Induced pluripotent stem cells offer new approach to therapy in thalassemia and sickle cell anemia and option in prenatal diagnosis in genetic diseases. Proc Natl Acad Sci U S A (2009) 106(24):9826-30. doi:10.1073/pnas.0904689106

115. Hu K, Yu J, Suknuntha K, Tian S, Montgomery K, Choi KD, et al. Efficient generation of transgene-free induced pluripotent stem cells from normal and neoplastic bone marrow and cord blood mononuclear cells. Blood (2011) 117(14):e109-19. doi:10.1182/blood-2010-07-298331

116. Bedel A, Pasquet JM, Lippert E, Taillepierre M, Lagarde V, Dabernat S, et al. Variable behavior of iPSCs derived from CML patients for response to TKI and hematopoietic differentiation. PLoS One (2013) 8(8):e71596. doi:10.1371/journal.pone.0071596

117. Morishima T, Watanabe KI, Niwa A, Hirai H, Saida S, Tanaka T, et al. Genetic correction of HAX1 in induced pluripotent stem cells from a patient with severe congenital neutropenia improves defective granulopoiesis. Haematologica (2014) 99(1):19-27. doi:10.3324/haematol.2013.083873

118. Carvajal-Vergara X, Sevilla A, D'Souza SL, Ang YS, Schaniel C, Lee DF, et al. Patient-specific induced pluripotent stem-cell-derived models of LEOPARD syndrome. Nature (2010) 465(7299):808-12. doi:10.1038/nature09005

119. Moretti A, Bellin M, Welling A, Jung CB, Lam JT, Bott-Flügel L, et al. Patientspecific induced pluripotent stem-cell models for long-QT syndrome. N Engl J Med (2010) 363(15):1397-409. doi:10.1056/NEJMoa0908679

120. Yazawa M, Hsueh B, Jia X, Pasca AM, Bernstein JA, Hallmayer J, et al. Using induced pluripotent stem cells to investigate cardiac phenotypes in Timothy syndrome. Nature (2011) 471(7337):230-4. doi:10.1038/nature09855

121. Davis RP, Casini S, van den Berg CW, Hoekstra M, Remme CA, Dambrot C, et al. Cardiomyocytes derived from pluripotent stem cells recapitulate electrophysiological characteristics of an overlap syndrome of cardiac sodium channel disease. Circulation (2012) 125(25):3079-91. doi:10.1161/CIRCULATIONAHA. 111.066092

122. Sun N, Yazawa M, Liu J, Han L, Sanchez-Freire V, Abilez OJ, et al. Patient-specific induced pluripotent stem cells as a model for familial dilated cardiomyopathy. Sci Transl Med (2012) 4(130):130ra47. doi:10.1126/scitranslmed.3003552

123. Itzhaki I, Maizels L, Huber I, Zwi-Dantsis L, Caspi O, Winterstern A, et al. Modelling the long QT syndrome with induced pluripotent stem cells. Nature (2011) 471(7337):225-9. doi:10.1038/nature09747

124. Matsa E, Rajamohan D, Dick E, Young L, Mellor I, Staniforth A, et al. Drug evaluation in cardiomyocytes derived from human induced pluripotent stem cells carrying a long QT syndrome type 2 mutation. Eur Heart J (2011) 32(8):952-62. doi:10.1093/eurheartj/ehr073

125. Lahti AL, Kujala VJ, Chapman H, Koivisto AP, Pekkanen-Mattila M, Kerkelä E, et al. Model for long QT syndrome type 2 using human iPS cells demonstrates arrhythmogenic characteristics in cell culture. Dis Model Mech (2012) 5(2):220-30. doi:10.1242/dmm.008409

126. Fatima A, Xu G, Shao K, Papadopoulos S, Lehmann M, Arnáiz-Cot JJ, et al. In vitro modeling of ryanodine receptor 2 dysfunction using human induced pluripotent stem cells. Cell Physiol Biochem (2011) 28(4):579-92. doi:10.1159/000335753

127. Jung CB, Moretti A, Mederos y Schnitzler M, Iop L, Storch U, Bellin M, et al. Dantrolene rescues arrhythmogenic RYR2 defect in a patient-specific stem cell model of catecholaminergic polymorphic ventricular tachycardia. EMBO Mol Med (2012) 4(3):180-91. doi:10.1002/emmm.201100194

128. Kujala K, Paavola J, Lahti A, Larsson K, Pekkanen-Mattila M, Viitasalo M, et al. Cell model of catecholaminergic polymorphic ventricular tachycardia reveals early and delayed after depolarizations. PLoS One (2012) 7(9):e44660. doi:10.1371/journal.pone. 0044660

129. Di Pasquale E, Lodola F, Miragoli M, Denegri M, Avelino-Cruz JE, Buonocore $\mathrm{M}$, et al. CaMKII inhibition rectifies arrhythmic phenotype in a patient-specific model of catecholaminergic polymorphic ventricular tachycardia. Cell Death Dis (2013) 4:e843. doi:10.1038/cddis.2013.369

130. Kim C, Wong J, Wen J, Wang S, Wang C, Spiering S, et al. Studying arrhythmogenic right ventricular dysplasia with patient-specific iPSCs. Nature (2013) 494(7435):105-10. doi:10.1038/nature11799

131. Weick JP, Held DL, Bonadurer GF III, Doers ME, Liu Y, Maguire C, et al. Deficits in human trisomy 21 iPSCs and neurons. Proc Natl Acad Sci U S A (2013) 110(24):9962-7. doi:10.1073/pnas. 1216575110

132. Li Y, Tsai YT, Hsu CW, Erol D, Yang J, Wu WH, et al. Long-term safety and efficacy of human-induced pluripotent stem cell (iPS) grafts in a preclinical model of retinitis pigmentosa. Mol Med (2012) 18:1312-9. doi:10.2119/ molmed.2012.00242

133. Ma D, Wei H, Lu J, Ho S, Zhang G, Sun X, et al. Generation of patientspecific induced pluripotent stem cell-derived cardiomyocytes as a cellular model of arrhythmogenic right ventricular cardiomyopathy. Eur Heart J (2013) 34(15):1122-33. doi:10.1093/eurheartj/ehs226

134. Ye Z, Zhan H, Mali P, Dowey S, Williams DM, Jang YY, et al. Human-induced pluripotent stem cells from blood cells of healthy donors and patients with acquired blood disorders. Blood (2009) 114(27):5473-80. doi:10.1182/blood2009-04-217406

Conflict of Interest Statement: The authors declare that the research was conducted in the absence of any commercial or financial relationships that could be construed as a potential conflict of interest.

Received: 20 November 2013; paper pending published: 10 December 2013; accepted: 05 March 2014; published online: 24 March 2014.

Citation: Botman $O$ and Wyns C (2014) Induced pluripotent stem cell potential in medicine, specifically focused on reproductive medicine. Front. Surg. 1:5. doi:10.3389/fsurg.2014.00005

This article was submitted to Gynecology and Obstetrics, a section of the journal Frontiers in Surgery.

Copyright $\odot 2014$ Botman and Wyns. This is an open-access article distributed under the terms of the Creative Commons Attribution License (CC BY). The use, distribution or reproduction in other forums is permitted, provided the original author(s) or licensor are credited and that the original publication in this journal is cited, in accordance with accepted academic practice. No use, distribution or reproduction is permitted which does not comply with these terms. 


\section{APPENDIX}

Table A1 | Diseases modeled with fully differentiated disease-specific iPSCs.

Disease models

Reference

Somatic cell source

Physiopathological

screening or drug testing

\section{METABOLIC DISEASES}

Lesch-Nyhan syndrome (carrier)

Gaucher's disease, type III

Type 1 diabetes

$\alpha 1-A n t i t r y p s i n$ deficiency

(78)

Glycogen storage disease la

Familial hypercholesterolemia

Crigler-Najjar syndrome

Hereditary tyrosinemia, type 1

Hurler syndrome

Mucopolysaccharidosis type IIIB

(84)

Niemann-Pick type C1

(85)

NEUROLOGICAL DISEASES

Parkinson's disease

Huntington's disease

Familial amyotrophic lateral sclerosis

Familial dysautonomia

Rett syndrome

Spinal muscular atrophy

Angelman's syndrome

Prader-Willi syndrome

Friedriech's ataxia

(103)

Schizophrenia

Machado-Joseph disease

Childhood cerebral Adrenoleukodystrophy and

Alzheimer's disease

Warkany syndrome 2 X-linked adrenoleukodystrophy

Emanuel syndrome

(20)

Fibroblast

Fibroblast

Fibroblast

Fibroblast

Fibroblast

Fibroblast

Fibroblast

Fibroblast

Fibroblast

Fibroblast

Fibroblast

Fibroblast

Fibroblast

Keratinocyte

Fibroblast

Fibroblast

Fetal cortical progenitor

Fibroblast

Fibroblast

Fetal lung fibroblast

Bone marrow mesenchymal stem cells

Fibroblast

Fibroblast

Fibroblast

Fibroblast

Fibroblast

Fibroblast

Fibroblast

Fibroblast

Fibroblast

Fibroblast

Fibroblast

Fibroblast

Fibroblast

Fibroblast

Fibroblast

Fibroblast

Fibroblast

Fibroblast

Fibroblast

Fibroblast

Fibroblast

Fibroblast

Fibroblast

Amniocyte

Fibroblast

Amniocyte

Fibroblast
N

Y

N

N

N

N

Y

N

N

Y

N

Y

N

Y

N

Y

N

Y

Y

N

Y

N

N

N

Y

Y

Y

N

N

Y

N

Y

N

N

N

Y

Y

Y

Y

Y

Y

Y

N 
Table A1 | Continued

Disease models

Reference

Somatic cell source

Physiopathological

screening or drug testing

\section{RETINOPATHIES}

Gyrate atrophy

Retinitis pigmentosa

Usher syndrome

Leber's hereditary optic neuropathy

\section{IMMUNE AND BLOOD DISEASES}

\section{Fanconi's anemia}

$\beta$-Thalassemia

Polycythemia vera

Primary myelofibrosis

Sickle-cell anemia

Scleroderma

Chronic myeloid leukemia disease

Severe congenital neutropenia

\section{CARDIOVASCULAR DISEASES}

\section{LEOPARD syndrome}

Long-QT 1

Timothy syndrome

Overlapping $\mathrm{Na}^{+}$channel disease syndrome

Familial dilated cardiomyopathy

Long-QT 2

$\begin{array}{lr}\text { Catecholaminergic polymorphic ventricular } & (124) \\ \text { tachycardia } & (125) \\ & (126) \\ & (128) \\ \text { Arrhythmogenic right ventricular } & (129) \\ \text { cardiomyopathy } & (133)\end{array}$

\section{OTHER DISEASES}

Down syndrome

Cystic fibrosis

Recessive dystrophic epidermolysis bullosa

Patau syndrome

Klinefelter syndrome

(109)

(110)

(111)

(132)

(112)
(134)

(80)

(115)

(116)

(117)

(118)

(119)

(120)

(121)

(122)

(123)

124)

125)

(126)

127)

130)

83)

(43)
Fibroblast

Fibroblast

Fibroblast

Fibroblast

Fibroblast

\section{Y}

N

Y

Y

N

$\mathrm{N}$

N

33)
Fibroblast

Fibroblast

CD34+ cel

Fibroblast

Fibroblast

Fibroblast

CD34+ cell

Fibroblast

Fibroblast

Fibroblast

Fibroblast

Fibroblast

Fibroblast

Fibroblast

Fibroblast

Fibroblast

Fibroblast

Fibroblast

Fibroblast

Fibroblast

Fibroblast

Fibroblast

Fibroblast

Fibroblast

Fibroblast

Fibroblast

Keratinocyte

Amniocyte

Fibroblast

Fibroblast
N

N

N

N

N

N

$\mathrm{N}$

N

N

N

N

Y

N

Y

Y

Y

Y

Y

Y

Y

Y

Y

N

Y

N

N

N

Y

N 